\title{
Den oldengelske digtning og Grundtvig
}

\author{
Af Bent Noack
}

Den oldengelske digtning hører til den del af den engelske bogog litteraturhistories skriftlige frembringelser som er blevet til i den tidlige middelalder, rundt regnet mellem år 600 og år 1066. Årstallet 600 sigter til det afgørende, at pave Gregor den Store kort før det århundredskifte sendte Augustinus til England for at vinde de engelske kongeriger for den romerske form for kirke og kristendom, brutalt sagt: erobre den engelske kristenhed, som den irokeltiske mission indtil da havde haft størst indflydelse på. Den forbindelse, som dermed blev indgået, skulle vise sig at blive særdeles frugtbar. Disse fire-fem århundreder skabte det samspil mellem saxisk sprog, nordisk islæt fra angler og jyder og irokeltisk arv på den ene side og på den anden side den romerske og latinske kristendom med dens latinske sprog, dens kirkeorganisation og kirkelige litteratur, en forbindelse som overlevede den 'normanniske erobring', der ellers satte punktum for den oldengelske tidsalder i snævrere forstand.

Når vi kalder den oldengelsk, følger vi den mest udbredte danske og engelske sprogbrug. Men Grundtvig taler konsekvent om det angelsaxiske sprog og den angelsaxiske digtning. Han var ganske klar over det angelsaxiske sprogs oprindelse og nærhed til det oldhøjtyske og dets forskellighed fra oldnordisk, og han vidste også, at den angelsaxiske litteratur stort set slutter med normannernes erobring. Når noget fra senere tid optager ham, som det er tilfældet med Layamons Rimkrønike fra først i det 13. århundrede $^{l}$, var det fordi den efter normannisk-fransk forlæg er skrevet p̊̊ angelsaxisk. For Grundtvig er angelsaxisk et hædersnavn, normannisk et skældsord. Man overraskes ikke ved at læse hos Grundtvig, at Morten Luther var angelsaxisk ${ }^{2}$. Den store samlede udgave af den oldengelske digtning hedder da også 'The AngloSaxon Poetic Records'.

Indholdet af disse bind, som hidrører fra forskellige håndskrifter i flere bibliotekers eje, er ret broget og rummer bl.a. gåder og ordsprog og kortere digte; men de væsentlige dele falder i to 
grupper, heltekvad og bibelsk digtning, herunder også helgenlegender.

Heltekvadenes vigtigste stykke er 'Bjovulf', en bog på godt 3000 vers, og det er også det største samlede stykke i den litteratur; det er endelig også den digtning som har været kendt længst, altså tidligst er draget frem, udgivet og gengivet.

Den bibelske digtning er den der gerne går under de hævdvundne navne Kædmon og Kynevulf, som Grundtvig også bruger. Om Kædmon vides det gennem Beda Venerabilis, ${ }^{4}$ hvornår omtrent han levede, nemlig i slutningen af det 7. årh.; men bortset fra nogle få linjer kan man ikke med nogen som helst sikkerhed tillægge ham det ene eller det andet stykke i digtningen. Kynevulf giver sig selv til kende som digteren ved at bruge sit navns bogstaver i runeskrift puttet ind mellem de almindelige skrifttegn; til gengæld vides det så ikke om ham, hvornår han har levet og digtet. Den bibelske digtning fortæller, i forskellige håndskrifter, om englefaldet, skabelsen og syndefaldet, nedfarten til helvede, himmelfarten og dommedag. Dertil lægger sig i emne og stil "Drømmen om Korsets Træ" ${ }^{15}$ og de stykker der er skrevet over adventstidens antifoner, og som derfor sammenfattes og er udgivet under navn af "Adventsdigtningen". ${ }^{6}$ Også nogle gammeltestamentlige texter findes i gendigtning og genfortælling, blandt dem den apokryfe Judiths Bog. De vigtigste stykker af helgenlegenderne er "Juliana" og beretningen om kejserinde Helena, der i Jerusalem finder Kristi kors.

Det karakteristiske er nu, at selv om heltedigtningen og den bibelske digtning kan synes at være to vidt forskellige grupper med adskilte emner, er der digtet om dem på samme sprog, i samme stil og versemål, det som vi kender fra den oldnordiske digtning, med frit antal stavelser, men bestemt antal trykstærke, og med stramme regler for stavrimenes plads. Og ikke nok med stilen og sproget, også ånden og holdningen er ikke bare i slægt med hinanden, men de samme. En række af de bibelske digtninger kan med lige så stor ret kaldes for heltekvad, i dem er det blot Kristus som er helten, kongen, krigeren, med sin hird omkring sig, sine svende og trofaste mænd, som de kaldes. Hvor dybt det stikker, kommer måske ikke engang tydeligst frem i versene om nedfarten til helvede eller i stykket om himmelfarten, men i "Drømmen om Korsets Træ". I det digt slåes der ikke noget af på skildringen af 
Jesu lidelse; den er udmalet så godt, som man ellers plejer at påstå at det er den sene middelalders sag at gøre det, så det er halsløs gerning at ville spille forsoning og forløsning ud mod hinanden på det grundlag. Men samtidig skildres den lidende Kristus som kæmpe og helt:

Den unge kæmpe, den altrådende Gud, aflagde sin klædning, helhjertet og stærk, for alles øjne steg han op på korset med kongeligt mod for at frelse os.

Og på den anden side: Bjovulfs Drape, for nu at bruge Grundtvigs navn for det, er overleveret af de samme kredse som vi skylder vort kendskab til den bibelske og øvrige kristne digtning, nemlig de kristne klerke; og det er ganske vist ikke et kristent digt med bibelsk emne, men de gode klerke har også taget det til deres hjerte. I begyndelsen af Bjovulf hedder det om kvadene der lyder i hallen:

Nu udholdt uhyret, ondt og farligt, et sugende savn, hvor han sad i mørket og dag efter dag hørte døn af glæde højt i hallen; der var harpeklang, skjaldens klare sang. Den kyndige vidste at fortælle, hvordan mennesker blev til i begyndelsen, han sagde, at Skaberen skabte jorden, den dejlige vang, som vandet omfavner, sejrsglad satte han solen og månen, lys til at skinne for skabte på jord, og han prydede hver en plet $i$ verden med grene og løv, også liv lod han blive for alle arter, som iler omkring .-.

og der fortsættes i de næste linjer med Kains brodermord og straffen for englefaldet. Der er mange flere klart kristne passager og udtryk, og det har da også været drøftet, efter bedste litterærkritiske metode, om de skulle være senere kristne indskud i en oprindelig hedensk digtning. I litterær forstand er de det ikke. Som Bjovulfkvadet foreligger, er det et digt fra kristen tid. 
Emnet fra sagnhistorien er gammelt, og det har der været fortalt om langt tilbage, men som vi kender det, er det fortalt og gendigtet $\mathrm{i}$ en tid, da den nordiske arv og kristendommen ikke blot levede side om side, men var forenet til en helhed.

Det var Bjovulfkvadet som blev Grundtvigs vej til den oldengelske digtning, og det var historikeren Grundtvig som fandt den. "Fædrelandets Historie var stedse min Kjephest", som han skriver i den lange dagbogsoptegnelse under 31. dec. $1804,{ }^{8}$ hvor han omtaler hvordan P.N. Skovgaard vakte hans lyst til islandsk. Grundtvig hører til det kuld der genopdagede oldtiden og middelalderen, en opdagelse der $\mathrm{i}$ det hele taget kendetegnede romantikken. Efter lange tiders glemsel skulle folkets gamle historie og overlevering atter frem til fuldt lys. Herhjemme havde allerede Johannes Ewald taget et nordisk emne op, og senere blev både Oehlenschläger og Ingemann, og altså Grundtvig med, optaget af fortidens historie og sagn. Det er kendt at perioden for alvor indvarsledes med Steffens' forelæsninger i vinteren 1802 03, som både Blicher og Grundtvig og andre senere berømtheder hørte; men det er ganske spændende at tænke på, at allerede før Oehlenschläger skrev "Guldhornene" og før Steffens holdt sine forelæsninger, havde den attenårige Grundtvig i 1801 skrevet en række digte om sagnhistoriske emner.

Da han så $\mathrm{i}$ de følgende år arbejdede med stoffet, indgik naturligvis Bjovulf $\mathrm{i}$ hans studier, og i frugten af arbejdet, Nordens Mytologi 1808, fremsatte han ønsket om en udgave af digtet. Da var han 25, og han sluttede sit arbejde med digtet i 1865, da han var 82, efter gang på gang at være vendt tilbage til det.

Den efterlyste udgave af manuskriptet til Bjovulf kom i 1815, og det var Thorkelin som besørgede den. Dermed begynder Grundtvigs arbejde ikke blot med indholdet, men også med formen. Allerede i udgivelsesåret anmeldte Grundtvig Thorkelins udgave i "Nyeste Skilderie af Kjøbenhavn" og oversatte her selv den første sang til dansk. Senere i samme tidsskrift, da Thorkelin havde fremsat sine indvendinger mod anmeldelsen, optrykte Grundtvig et enkelt parti på angelsaxisk med sin egen oversættelse samt en prosaoversættelse. I den digteriske gengivelse viser Grundtvig allerede et væsentligt træk i sin oversættervirksomhed: han bruger langt flere linjer end den angelsaxiske original, og det 
er ikke af uformuenhed, men ud fra en overbevisning om at troskaben mod originalen kræver det, hvis man også vil være tro mod dansk sprog og stil. ${ }^{9}$ Han fulgte sin kritik af Thorkelin op i Danevirke II, 1817 med afhandlingen "Om Bjovulfs Drape, eller det af Hr. Etatsraad Thorkelin 1815 udgivne angelsachsiske Digt", og i Danevirke IV trykte han et par år efter "Stykker af Skjoldung-Kvadet eller Bjovulfs Minden.10

I mellemtiden havde han lært angelsaxisk. Som næunt havde han været inde på islandsk længe før, og allerede under forstudierne til Nordens Mytologi blev han klar over forbindelsen mellem en række oldnordiske og angelsaxiske ord; lidt oldhøjtysk havde han også studeret. Da så Thorkelins udgave kom, gav han sig til at læse angelsaxisk, en tid sammen med Rasmus Rask, der i 1817 selv udgav en angelsaxisk grammatik. At der var planlagt et nøjere samarbejde mellem de to, fremgår af en passus i den sidstnævnte artikel: "For det første blev der intet af den nye Udgave, hvortil det gamle Digt saa høilig trænger, men naar Professor Rask kommer tilbage, tænker jeg vi udføre vort Forsæt". 11

Da Rask endelig vendte hjem i 1823, var Grundtvig optaget af andre sager, og det var først under Englandsrejserne i 1829, 1830 og 1831 at han for alvor kom i gang med den oldengelske litteratur. Det blev da atter først og fremmest Bjovulf, og i sin audiens hos Frederik den VI havde Grundtvig da også slået på den betydning de angelsaxiske skrifter havde for studiet af Danmarks oldtid. Men det blev som bekendt ret hurtigt til en langt mere omfattende plan, nemlig en udgivelse i selve England af en række af "the most valuable anglo-saxon manuscripts, illustratives of the early poetry and literature of our language", d.v.s. det engelske, som det hed i den "Prospectus and Proposals" for et "Bibliotheca Anglo-Saxonica", som Grundtvig fik trykt i England i 1831. ${ }^{12}$ Det blev nu ikke til noget, Benjamin Thorpe tog ideen op og fik den virkeliggjort. Men givet er det at det var gennem Thorkelins arbejde og ikke mindst Grundtvigs virksomhed i England, at englænderne blev opmærksomme på, hvilke værdier de lå inde med. I brevene fra Englandsrejserne, til Lise Grundtvig, til Ingemann og til Molbech, og siden både i "Af Mands Minde" og i "Kristenhedens Syvstjerne", bliver han ikke træt af at 
undre sig over hvor lidt selv lærde "Engellændere" kender til de skjulte skatte. ${ }^{13}$

Men det fejlslagne fors $\emptyset \mathrm{g}$ standsede ikke Grundtvigs arbejde med de angelsaxiske texter, han gik som nævnt videre med Bjovulf livet igennem, skrev om den i "Brage og Idun" i 1841 og fik sin egen udgave ud i 1861, som han oven i købet forsynede med et kvad som han selv havde skrevet på angelsaxisk. Og det blev ikke hans eneste udgivelse: i 1840 udgav han "Phenix-Fuglen, et angelsachisk Kvad, førstegang udgivet med Indledning, Fordanskning og Efterklang". Alt det kan der læses om i Fr. Rønnings stadig vigtige arbejde om Grundtvig og den oldengelske Litteratur i Historisk Maanedsskrift IV, $18855^{14}$

Det var et kæmpearbejde Grundtvig gjorde med den oldengelske digtning. Allerede det at beherske sproget $\mathrm{i}$ det omfang som var nødvendigt for virkelig at sætte sig ind $i$ den og arbejde videnskabeligt med den, krævede grundige videnskabelige studier. Dertil kom så under hans Englandsrejser arbejdet med at finde manuskripterne og få adgang til dem, og hvad det tog af tid og tanker får man et godt billede af i Englandsbrevene. Så først begyndte lasningen af håndskrifterne og afskrivningen af dem. Endelig udgivelsen, der krævede filologisk viden og håndelag og, hvad Grundtvig er et fremtrædende exempel på, intuition. Begge dele viste han allerede $i$ sin kritik af Thorkelin og siden ved sine to udgaver, af Bjovulf og af Fønixfuglen. Han får da også i moderne udgaver fortjent anerkendelse for sit arbejde; adskillige af hans læsninger og konjekturer er stadig godkendt som de rigtige, som det f.ex. kan ses i Wyatt og Chambers' Bjovulfudgaves indledning og noter. ${ }^{15}$ Det er rigtigt, som Helge Toldberg siger, at filologien kun var det nødvendige værkt $\varnothing j$ for historikeren og digteren og folkeoplyseren Grundtvig, men det gør kun hans arbejde på dette område så meget mere imponerende.

Vel var det altså historikeren Grundtvig der af kongen blev sendt på de tre rejser til England. Men det var ikke bare historie og textudgaver der kom ud af hans ophold i England. Det blev også præsten og salmedigteren, hvis man ellers kan skelne sådan mellem Grundtvigs forskellige sider, der fik noget ud af studierne af den oldengelske digtning. Fra Bjovulf gik han videre til den bibelske og kirkelige del af den. Under den anden Englandsrejse 
besøgte han Exeter, hvor han vidste at det manuskript, som nu kaldes Exeterbogen, lå, et manuskript som englænderne nok havde udgivet, men lykkeligt glemt igen. Som Grundtvig skriver i "Dansk Ravnegalder":

Det brittiske Museum - - -

-- voved os at skamme ud,

fordi en gammel Skrolle

med Angelsviser stoppet fuld,

i Exeter begravet, end ikke i syvhundred Aar

engang var efterskrevet.

Grundtvig opdagede dog at englænderne var blevet opmærksomme på manuskriptet og ville have det overført til London, så han skyndte sig til Exeter ${ }^{16}$ og studerede manuskriptet inden det kom til London, hvor Robert Chambers skrev det af i 1831-32.

Bekendtskabet med Exeterbogen blev på et andet område af lige så stor betydning for Grundtvig og hans digtning som Bjovulf, og for os danske er det nok det som har sat sig de varigste og bredest påskønnede spor. Få år efter sin tredie Englandsrejse, i 1835, gik Grundtvig nemlig i gang med det af sine værker som, ikke $\mathrm{i}$ sin helhed, men i sine væsentlige dele, er blevet mere folkeeje end noget andet han har skrevet, Sangværkets første bind fra årene 1836-37.

For at få klarhed over hvorfor og hvordan Grundtvig i Sangværket bruger den angelsaxiske digtning, må man tage den store sammenhæng med, som hans brug af den indgår $i$, den opbygning, eller rettere dobbelte opbygning, der præger Sangværkets første bind. Den grove inddeling falder i to: kirken, gudstjenesten, dåb og nadver som den første halvdel, og så, fra nr. 147, i store træk efter kirkeåret: Advent med de gammeltestamentlige profetier, Jul, Påske, Himmelfart og Pinse, sluttende til kirkeårets sidste søndage med "Rejs op dit hoved, al kristenhed" og "Sørger ej for dem, der sove". ${ }^{17}$ Men inden for disse afsnit går Grundtvig frem efter det skema som mange år efter blev fuldt udfoldet $\mathrm{i}$ Kristenhedens Syvstjerne, men som havde optaget ham helt fra de unge år: de syv, eller rettere endnu kun sex folkemenigheder, som 
han fandt forudsagt og beskrevet i de syv menighedsbreve $\mathrm{i}$ Åbenbaringsbogen: den ebræiske, den græske, den latinske, den engelske, den tyske og den nordiske. Af de syv er den engelske altså den midterste, og også den der vender nedgangslinjen til en opgangslinje, den nederste bue $\mathrm{i}$ en parabel med spidsen nedad; den er den tap som historien drejer sig om; i hvert fald, med Grundtvigs egne ord i Syvstjernen:

Klarlig danner overgangen du fra øst og syd til nord.

Grundtvigs kendskab til den angelsaxiske digtning gør nu, at han i sin "engelske" afdeling eller rettere de engelske afdelinger, ikke nøjes med at oversætte engelske salmer fra nyere tid, af Watts og Wesley og andre, men indleder dem, historisk!, med gendigtning af oldengelske texter, som således $i$ hans pen bliver til salmer. To af dem er blevet stående og synges stadig: "I kveld blev der banket paa Helvedes Port" og "Kommer, Sjæle, dyrekiøbte". Men der er adskilligt flere.

Den første er nr. 124, altså i "kirkedelen" af Sangværkets første bind:

Høiere end Huus og Hald,

Drot i Himmel-Sale!

"Af den Angel-Sachsiske Messiade i Exeter-Bogen" skriver Grundtvig i sin fodnote til den. Jeg har andet steds ${ }^{18}$ prøvet at vise at noternes udtryk ikke er tilfældige, men at "omsat", "efterlignet", "frit oversat", "efter" og "af" betegner stigende grader af troskab mod forlægget, uden at den dog altid er lige stor, når der siges "af". Her er forlægget det første af de stykker af "Christ", som man samlet har udgivet under navnet "Adventsdigtning", men, ligesom i Grundtvigs første digteriske gengivelse af et stykke af Bjovulf, meget betegnende kraftigt udvidet til ti syvlinjede vers, der også inddrager motiver fra andre stykker af Adventsdigtningen. Et par exempler må være nok: Exeterbogens: "Din ret er at være hovedstenen i den store højsal og sammenføje de lange vægge så stærke som flinten - -. Rejs snart dit hus fra væg til væg; dit værk trænger hårdt til at mesteren kommer, at kongen selv vil 
genrejse det som nu ligger knust", går igen hos Grundtvig som: "Se i Naade til dit Huus! - - - Lad nu brat sig Kridt og Flint/ Konstig sammenføie,/ Kirke-Væg som Klippe-Klint/staa for Verdens Øie!"

Den næste i rækken står i "højtidsdelen" og er en julesalme, nr. 158, og den er atter ifølge noten "af" Exeterbogen, men alligevel en noget bredere gengivelse af et par stykker $i$ den (svarende til Antifon VIII og IX) og med en lang række overensstemmelser. I Exeterbogen begynder stykket: "Retfærdige Hersker, / du fredens Fyrste, / du Kongernes Konge,/ almægtige Krist", og Grundtvigs indledning svarer til det: "Sanddru og Fredegod!/ Frelser med Guddoms-Blod!/ Alle Kongers Konning!/ Christus! vor Drot forsand!". Til Exeterbogens fortsættelse, at "der er ingen - - så viis, så snild og så klog, - - - at han kan fortælle for havets børn, hvordan Himlens Herre i begyndelsen havde dig som Guds kære Søn", svarer Grundtvigs vers 2: "Hvordan i Himmerig / Hemmelig fødte Dig / Evigheds Alfader, / Jordbo ej grunder ud". I Exeterbogen er "det første, vi mennesker hørte - om skabelsens dage - - at Gud skilte lys fra mørke", i Grundtvigs vers 4 er det samme "Frasagnet, først af Alt / Fyndig paa Jord fortalt". Også de følgende af Grundtvigs 14 vers går frem efter forlægget. Det gælder vers 7 med dets brug af billedet "den gyldne port", der, igen som i forlægget, bruges en gang til (motivet fra Ezek. 44,1-2) og tages om "Maria Mø" som den port som Jesus drager ind i verden igennem. Det gælder også Exeterbogens linjer: "Den skumle død, den forbandede ulv, har spredt dine făr og splittet din hjord", som Grundtvig benytter i sine vers 8 og 9: "Vantro er Fjendens Værk, / Var-Ulvens, jettestærk,/ som din Hjord skambider,/ Hjorden, som, Hyrde god! / kosted dit HjerteBlod,/ Kaad han sønderslider! - - Kiør ham i Helved ned!"

De næste tre er numrene 243-45: "I Kveld blev der banket paa Helvedes Port", "Efter Angel-Sachseren hos Cædmon", som det hedder i noten, "Kommer, Sjæle, dyrekiøbte", "Af den Angelsachsiske Messiade i Exeter-Bogen", og "Himmel-Farten saae i Løn / Salomon, Kong Davids Søn", "Af Messiaden i Exeter-Bogen, med Hensyn paa Høisangens 2det." De to første er kendt, den sidste mindre, men den viser Grundtvigs troskab mod forlægget. Efter den foregående er han gået videre i Exeterbogen og har fundet motivet (som er oldkirkeligt) "Jesu 6 Spring": fra himlen til 
Jomfruens skød, fra det til krybben, fra livet op på korset, fra korset ned i graven, det femte ned i helvede, det sjette himmelfarten. Også slutningen på den salme følger forlægget, når den siger, at vi skal "Springet efterligne -- Saa og vi med Aanden Hans / Stige skal fra Glands til Glands, / Til vi naae Guld-Kronen!". Det mest iøjnefaldende er dog at Grundtvig blot et par numre før, i Nr. 242, "Kæmpe-Skridt, som ingen Anden, /Tager Christus, Guddoms-Manden", har skrevet over det samme motiv i en latinsk hymne; nr. 245 er altså for så vidt en gentagelse; men det er Grundtvig så meget om at gøre, at ikke blot latineren, men også angelsaxeren kommer til orde, at han skriver endnu en salme med det motiv, som da også er ret forskellig fra den med det latinske forlæg.

Den sidste i Sangværkets første bind er nr. 355, "Takker den Herre, som Sorgen omvendte/ Naadig til Glæde og Sukket til Sang", med det gamle motiv om Kristus som solen og kirken som månen, svarende til Exeterbogens "Krist er det trofaste solens lys, et strålende skær for engle og folk. Over jord skinner månen, en stjerne, der frygtes: sådan skinner Guds kirke, hvor retten og sandheden møder hinanden".

Når Grundtvig højt op i sin alderdom arbejdede med det oldengelske, sprogligt, men så afgjort for indholdets skyld, er det klart, at den digtning har sagt og givet ham noget; naturligvis noget som han $\mathrm{i}$ forvejen var anlagt på at tage til sig, men det bliver det ikke uvæesentligt af.

Som digter blev han betaget af de poetiske udtryk og vendinger, som den digtning vrimler med, og som præger den i højere grad end den oldnordiske, som er mere barsk og knap. Adjektiverne fylder meget: "den fagre kvinde", "den dejlige m $\varnothing$ ", "ædle krigere", "den strålende sol", "de frådende bølger" o.s.v. Skibene er "havets heste" eller "vor ganger", jorden er "den vidtstrakte flade"; bedst kendt er vel "hvalernes veje" om havet, som Grundtvig også har fra det oldengelske.

Som nævnt ovenfor fik Grundtvig gjort den engelske, og det vil først og fremmest sige den angelsaxiske folkemenighed, til den midterste i rækken. Og særlig den oldengelske digtning, både heltedigtningen og den kristne, bringer for Grundtvig sammenhæng i historien, både Danmarkshistorien og kirkehistorien, "den kristne menigheds levnedsløb". Han havde historisk viden og 
forståelse og klart blik for de strømninger der udgør både vores og kirkens historie. Den forbindelse der havde været mellem Norden og England i vikingetiden, var hans udgangspunkt. Men han havde i høj grad sans for hvad den angelsaxiske og engelske kirke har bevaret og formidlet af oldkirkens tro og skikke og litteratur.

Måden som den formidling er sket på, har også sin betydning. Den er naturligvis for en væesentlig del sket gennem studiet af de græske og latinske kirkefædre og den praktiske brug af deres skrifter i salmer og prædikener og bønner og andet som hører kirkens liv til. Men det afgørende er at den også er sket $\mathrm{i}$ form af de fortællende digte. Det er virkelig bibelhistorie der fortælles, og den udmales med kærlighed og kunst, med dramatisk styrke og med virkelig indføling.

Den sidste kommer frem både $\mathrm{i}$ ordskiftet mellem Adam og Eva efter syndefaldet: "Med rette bebrejder du mig med din tale, min elskede Adam. Men du kan ikke angre det mer i dit hjerte, end jeg gør i mit", og i det mellem Josef og Maria efter at Josef har opdaget at Maria er frugtsommelig; Maria: "Ak, du min Josef, Jakobs søn, du Davids ætling, den store konges, må du nu bryde kærligheds bånd, holde op med at elske?", og Josef: "hvor let kunne Gud dog mildne den sorg jeg bærer i hjertet og trøste mig stakkel! Ak, unge kvinde, Jomfru Maria!". Hvor meget det så end er blevet til i klostrene og deres skoler, er det agte folkelig digtning.

Og den har talt til Grundtvig. Trods alle de forskelle som der også er, har han følt slægtskabet med det folkeliv han kendte herhjemmefra, fra Sydsjælland med Malenes fyndord og viser, fra Thyregod og fra ordsprogene, som tidligt optog ham og blev ved med at gøre det, og endelig med den oldnordiske digtning og først og fremmest dens fortællinger. Her fandt han folkeliv og kristendom forenet i sprog og udtryksmidler, ja i selve den måde hvorpå den bibelske historie er tilegnet.

Her er gjort det samme som Grundtvig ville: de bibelske og oldkirkelige mennesker og forhold, begivenheder og beretninger er omplantet til vore himmelstrøg. Som Grundtvig selv lader Jesus gå, ikke i ørkenen, men "Alt på den vilde hede", og lader David gå "på marken og vogte får" (hvor der så ganske vist er "løver og bjørne"), og flytter julen til Danmark i "Velkommen igen, Guds 
engle små", sådan har han af hjertet samtykket med angelsaxerne, når de digter om hav og sejlads og både og fiskeri, og lader det engelske vejrlig, eller for den sags skyld det danske, med tåge og blæst og regn og kulde være menneskers bosted og arbejdsplads. Her er evangeliet optaget i folkets liv, som Grundtvig ville have det $\mathrm{i}$ sin egen tid og i sit eget fædreland. Det gælder i lige måde heltedigtningen og den kristne digtning, at vi genkender vore egne kår og lidenskaber i dem. ${ }^{19}$

Men hvad nu særligt den kristne oldengelske digtning angår, har Grundtvig som kristen (han ville nok ikke selv have sagt teolog) følt sig hjemme i den og i den genfundet meget af det der for ham var det umistelige i kristendommen. Her skal kun nævnes et par enkelte punkter.

Først og fremmest evangeliet om Kristus og troen på ham, kristologien, for at tale fagsprog. Kristus er Guds Søn, og han er Gud. Det var et kernepunkt for Grundtvig, og det fandt han gang på gang udtrykt $\mathrm{i}$ den digtning, ikke blot $\mathrm{i}$ den, men også i den. Det kan godt være at dens kristologi slet ikke er gennemreflekteret, og det kan også godt tænkes at der i den er spor af Jesu underordning under Gud, når Kristus er "den som stråler mindre end Gud"; her kan man da, hvis man vil, finde en anelse underordning, der kan være en rem af arianismens hud; den er dog ikke mere påfaldende, end at den ikke har kunnet støde Grundtvig, og den strider jo da heller ikke mod Johannesevangeliets "Faderen er større end jeg". Men i det samme evangelium står der også: "Jeg og Faderen er ét". Det er det som er Grundtvigs urokkelige tro og prædiken, og det er lige sådan i den oldengelske kristne digtning. I Grundtvigs salmer kan det tit være svært at se, om han med "Herren" tænker på Gud eller på Kristus, og sådan skriver han ikke af vanvare. I den oldengelske digtning kan man finde det samme: kun når det er nødvendigt for fortællingens gang, skelnes der mellem Gud og Kristus, Guds Søn. I beretningen om skabelsen kaldes Gud, efter nytestamentligt forbillede, "vor Frelser", og han hedder "den trofaste drot", som også Kristus hedder den ene gang efter den anden. Og omvendt er Kristus ikke blot frelseren, men også skaberen. Som det hedder i stykket om nedfarten til helvede, med Evas ord: 
Du selv, min herre, fødtes til jord

ved en datter af mig til menneskers hjælp.

Det er åbenbart, at du er Gud,

den evige skaber for alt, som er skabt,

og det gentages lige efter:

Så førte den Evige skaren til himlen,

Der var fest og glæde, da flokken kom hjem

op til gården, ført af den Evige,

menneskers skaber.

Og det er "Guds egen Søn, som skabte vor verden", en tilspidsning, kan man gerne sige, af udsagnet i Joh. evg. 1,3.

Videre: Kristi gerning er forløsningen mere end den er forsoningen. Dermed skal ikke være sagt at angelsaxerne ikke kender og taler om forsoningen, Kristi kors og blod og offer. Men den tale fylder mindre end talen om forløsningen, den kamp, som Kristus fører mod alle onde magter, synden og døden og djævelen, og den sejr, som han ved sin heltedød, ved nedfarten til helvede, ved opstandelsen og himmelfarten, vandt, først og fremmest over døden, "den skumle død, den forbandede ulv", "varulven" i Grundtvigs gendigtning. Det var oldkirkelige toner, kendt bl.a. fra Irenæus. Dem havde Grundtvig også fundet i den græske hymnedigtning, som han brugte i 1836-37.

$\mathrm{Og}$ som det sidste i denne sammenhæng: Nedfarten til dødsriget, eller som han selv helst sagde, til helvede, fandt han udtrykkelig omtalt, og det så udtrykkeligt, som det led i trosbekendelsen ikke er nævnt i Det nye Testamente; hvad det betød for Grundtvig, har han selv sluttet sin gendigtning med: "Thi er det paa Jord nu en Saligheds-Sag:/ Guds Søn haver Helvede giæstet!"20

Spørger vi så til slut, hvad der for os kom ud af Grundtvigs arbejde med det oldengelske og hans brug af den kristne digtning, kan det ved første øjekast tage sig magert nok ud: en enkelt salme i salmebogen, "Kommer, sjæle dyrekøbte", og en sang eller salme, man kalde den hvad man vil, i Højskolesangbogen og 
enkelte andre steder. Arbejdet med Bjovulf er kun højst indirekte kommet os alle til gode.

Men statistik er ikke altid det sikreste bedømmelsesgrundlag.

Lige så lidt som Grundtvig kunne holde sin brug af denne digtning adskilt fra hvad han ellers brugte, både i Sangværkets første bind og i mange andre af digtene og skrifterne, Nordens Mytologi, de bibelhistoriske og historiske sange $\mathrm{i}$ det hele taget, lige så lidt kan vi isolere de to salmer, som nok er de eneste virkelig kendte og brugte. De må ses i sammenhæng ikke mindst med de oldgræske salmer med samme tone og tilsvarende indhold, for øvrigt også med f.ex. "Lad vaje højt vort kongeflag".

Dertil kommer så, at Grundtvigs sans for den oldengelske digtning og de salmer fra hans hånd som skyldes den, så vidt jeg kan se også har været med til at afgøre hvilke af den nyere tids engelske salmer Grundtvig kunne bruge, og også den måde han brugte dem på. For bare at nævne to: Det er ikke tilfældigt at Grundtvig kunne bruge Isaac Watts til "Syng højt, min sjæl, om Jesu død" og til "Halleluja for lysets drot"; der var noget i dem, som Grundtvig måtte fornemme som en videreførelse af den oldengelske digtning; og går man hans forlæg hos Watts efter, får man et indtryk af, hvordan Grundtvig har gjort dem endnu mere "oldengelske" i tonen, til dels også $\mathrm{i}$ indhold og billedbrug, foruden at han også ellers naturligvis har sat sit præg på dem.

Også i de salmer som han har skrevet uden udtrykkeligt forlæg, kan man mærke indflydelsen fra billeder og sprog i de oldengelske. Trods Johannes Ewalds "Udrust dig, Helt fra Golgatha" (og lignende træk kan findes hos Brorson!), er det på "oldengelsk", at Grundtvig et årti eller mere efter 1836-37 i salmebogens nr. 493, "Gud vi er i gode hænder", foruden den oldkirkelige hentydning til "Dine hænder, sang de gamle", også skriver "Helten under korsets mærke / han alene bandt den stærke", og i næste vers: "Synd og død og helveds plage, / som med ret ej kom ham ved, / bar korshelten uden mage, / bandt dem med sin kærlighed". Og han giver ikke blot Kristus navn af helt, han fortæller, bruger sætninger, om Kristi heltedåd.

Når den oldengelske digtning ikke kan isoleres, hverken $\mathrm{i}$ Grundtvigs forfatterskab og navnlig salmedigtningen eller $i$ vor brug af den, skal den alene da heller ikke have æren for at hele den kristendomsforståelse har fået så stor indflydelse i vores kirke. 
Men den er medvirkende. Uden Grundtvig havde Kragballe ikke oversat Beda, Hammerich ikke skrevet om den oldengelske digtning og Heliand i forlængelse af hinanden, Otto Møller formodentlig, trods al sin selvstændighed, heller ikke skrevet om genløsningen, og Joakim Skovgaard ikke malet sit billede af nedfarten til helvede.

1 Se Christian Molbech og Nikolai Frederik Severin Grundtvig. En Brevvexling, samlet af Chr.K.F. Molbech og udgivet af L. Schrøder, Kjøbenhavn 1888, s.154; jf. Grundtvig og Ingemann. Brevvexling, udgivet af Svend Grundtvig, Kjøbenhavn 1882, s.94.

2 J.P. Bang, Grundtvig og England, København 1932, s.113.

3 The Anglo-Saxon Poetic Records, Colombia Univ. Pr., N.Y. \& Routledge \& Kegan Paul, London, 1931-54.

4 Angler-Folkets Kirkehistorie af Beda den Ærværdige. Paa Dansk med Indledninger og Anmærkninger af Chr. M. Kragballe, Kjøbenhavn 1864, s.243-46.

5 Indledt og oversat af Arthur O. Sandved, "Drømmen om Kristi Kors", et kristent dikt i før-kristen form (i Kirke og Kultur 86, 1981, s.203-12).

6 Jackson J. Campbell, The Advent Lyrics of the Exeter Book, Princeton Univ. Pr. 1959.

7 Overs. af Andreas Haarder, Sangen om Bjovulf. I dansk gengivelse, København 1984, s.30.

Udv. Skr. I, s.66.

9 Til dette og det flg. jf. Helge Toldberg, Grundtvig som filolog, København 1946. 
10 Danne-Virke. Hhv. 1817, s.209-90 og 1819/20, s.234-62.

$11 \quad$ S.236.

12 Den fuldstændige text i N.F.S. Grundtvigs Englandsbreve til hans Hustru, udg. af deres Børnebørn, København 1920, note 132.

13 Se bl.a. Englandsbreve,m s.53 og 90, til Molbech s.154.

14 N. tidsskr. og årg., I, ss.321ff, og II, s.1ff og $129 \mathrm{ff}$.

15 N. udg. (1914) Cambr. Univ. Pr. 1968, s.xx: "- he made many conjectures which, on a more careful examination, were found to be actually the readings of the MS. Such success naturally aroused confidence in his conjectural restorations". Jf. også Helge Toldbergs anmeldelse af Kemp Malone, Grundtvig as Beowulf Critic, i Grundtvig Studier 1948, s.100-101.

Se Englandsbreve s.40.

17 Den første af dem er altså strengt taget ikke skrevet til 2.søndag i Advent, hvor vi mest bruger den.

"Baggrunden for salmen "Kommer, sjæle dyrekøbte"' (i Dansk Kirksangs Årsskr. 1981-82, s.83-99).

Det samme gælder til dels den oldsaxiske "Heliand". Men den kendte Grundtvig ikke; den blev først udgivet i 1830-40.

20 I denne forbindelse kan også nævnes sangen om englefaldet: "Herren, som raader i Himmerig" ("Efter et Brudstykke hos Angelsachseren Kædmon"), G.S. Bd.2, No.4, altså blandt de bibelhistoriske sange, som er mindre kendte og ikke synges. 